\title{
Ectopic Expression of Chloramphenicol Acetyltransferase (CAT) in the Cerebellum in Mice Transgenic for a Carbonic Anhydrase II Promoter-CAT Construct That Is Without Apparent Phenotypic Effect
}

ROBERT P. ERICKSON, ${ }^{1,2}$ ARTURO BEVILACQUA, ${ }^{1}$ PATRICK J. VENTA, ${ }^{1}$ JILL KAROLYI, ${ }^{1}$ AND RICHARD E. TASHIAN ${ }^{1}$

Departments of ${ }^{1}$ Human Genetics and ${ }^{2}$ Pediatrics and Communicable Diseases, University of Michigan Medical School, Ann Arbor, Michigan

\begin{abstract}
We have developed six transgenic lines of mice with constructs containing presumptive $5^{\prime}$ regulatory regions of carbonic anhydrase II (CA II). Four of the lines contained 1,100 bases of the $5^{\prime}$ flanking region of the human CA II gene, and two transgenic lines resulted from a construct containing 500 bases of the $5^{\prime}$ flanking region of the mouse CA II gene. Tissue-specific expression of the chloramphenicol acetyltransferase (CAT) gene was not obtained in any of the transgenic lines. One of the transgenic lines was found to have high levels of expression of CAT in cerebellum. This expression persisted through multiple generations and was independent of the parental origin of the transgene. On the assumption that the expression was due to the insertion of the transgene in or near a gene expressed normally in cerebellum, homozygous mice were bred for the transgenic insert to see if a mutation might have been induced. Homozygous mice were found and seemed to be normal in all aspects of their phenotype studied. Thus, in this case, neither the insertion of the gene nor the ectopic expression of CAT seemed to be harmful to the animals.
\end{abstract}

Key Words: Carbonic anhydrase II, Insertional genesis

\section{INTRODUCTION}

Carbonic anhydrase (CA) catalyzes the reversible hydration of carbon dioxide. Seven isozymes have so far been described in the multigene family (Tashian, 1989). In mice, the CA I, CA II, and CA III isozyme genes are tightly linked in the centromeric region of chromosome 3 (Eicher et al., 1976; Beechey et al., 1989); in man, CA I, CA II, and CA III are linked on the long arm of chromosome 8 (Edwards et al., 1986; Beechey et al., 1989). In humans, deficiency of CA I has been described with no clinical manifestations (Kendall and Tashian, 1977), whereas that for CA II has been found to produce pathological states of osteopetrosis, renal tubular acidosis, and cerebral calcification (Sly et al., 1983). Lewis et al. (1988) have recently produced a CA II-deficient mouse by an induced mutation that resulted in mice with reduced growth and renal tubular acidosis.

An interesting feature of the CA II gene in mammals is that it is expressed in almost all tissues, but only in a limited subset of cells (Tashian et al., 1984). Thus a variety of controlling elements may be expected to participate in the mechanism of regulation of CA II expression. The nucleotide sequence surrounding the first and second exon of the human and mouse CA II genes have been compared (Venta et al., 1985), with an overall percent identity of $81 \%$ and an even higher identity of $88 \%$ in the first exon. The region surrounding the TATA box is well conserved $(60 \%,-243$ to TATA; 69\%, TATA to ATG). The regions $700-800 \mathrm{bp}$ on either side of the first exon are extremely $\mathrm{G}$ and $\mathrm{C}$ rich. Such islands have been shown to be associated with the $5^{\prime}$ regions of many mammalian genes. About 90\% of methylated cytosines in mammalian DNA are found in the $\mathrm{CpG}$ sequence. This methylation is implicated in the control of gene expression in higher eukaryotes. A number of CCGCCC sequences have been found in the $5^{\prime}$ flanking regions. These sequences, first

Received February 16, 1990; accepted April 30, 1990

Address reprint requests to Dr. Robert P. Erickson, University of Michigan Medical School, Department of Human Genetics, 3704 Medical Science II, Ann Arbor, MI 48109-0618.

Arturo Bevilacqua's present address is Instituto di Istologia ed Embriologia Generale, Universita de Roma "La Sapienza," Via A. Scarpa, 14-00161 Roma, Italy. 
found near the origin of replication of SV40 and then reported on a number of genes (c-myc, alpha-globin, interleukin B, hydroxymethylglutaryl CoA-reductase), are important for the binding of a positive transcription factor called Spl. To study the role of these and other sequences in the tissue-specific and developmental regulation of CA II, we have been preparing transgenic mice with CA II constructs. Although we have not yet identified the essential controlling elements for CA II expression, we have identified one transgenic insertion that induces ectopic expression of the transgene construct. However, this insertional event seems to be without harmful effect, even in homozygous condition.

\section{MATERIALS AND METHODS \\ Generation of Transgenic Mice}

Mice of the SJL/J and $\mathrm{C} 57 \mathrm{Bl} / 6 \mathrm{~J}$ strains were purchased from the Jackson Laboratory and bred in our colony. Twenty-one-day-old $F_{1}$ females were used as donor animals for all experiments. They were primed with i.p. injections of 5 i.u. of pregnant male serum gonadotropin and with 5 i.u. human chorionic gonadotrophin $44 \mathrm{hr}$ later and subsequently mated with $\mathrm{F}_{1}$ males of the same strain. The following morning, onecell embryos were collected from the plugged females in standard medium (Hogan et al., 1986), and the DNA construct was injected into one of the pronuclei at a concentration of $1 \mathrm{ng} / \mu \mathrm{l}$. After an overnight culture at $37^{\circ} \mathrm{C}$ in $5 \% \mathrm{CO}_{2}$ in air, two-cell embryos were transferred into pseudopregnant CD-1 recipients and allowed to go to term (Hogan et al., 1986). Offspring were weaned at 21 days of age and subjected to tail biopsy for DNA extraction and Southern analysis. Transgenic lines were established by breeding founder animals with $F_{1}$ mice. After a line was successfully established, the founders and offspring were sacrificed for assay of CAT activity as described below.

\section{Preparation of Constructs}

Construct pHCA-CAT containing 1,100 bases of the 5 ' flanking region of human CA II gene ligated immediately upstream of the chloramphenicol acetyltransferase (CAT) gene in the pSV2CAT plasmid (Gorman et al., 1982) was prepared as described (Shapiro et al., 1987). The insert was purified by Bam HI and SphI digestion of the construct. Agarose gel electrophoresis of the digestion mixture and extraction with NA45 DEAE membrane (Schliecher \& Schuell) were subsequently performed, and the collected band was then resuspended in TE for injection. Construct pMCA-CAT, containing approximately 500 bases of the 5 ' flanking region of mouse CA II genes, was similarly introduced in the pSV2CAT plasmid as described. It was similarly purified by $B a m H I$ digestion and further treatment as described above.

\section{Dosimetry of Integrations}

Dosage was calculated from absorption measurements on a Zeineh soft laser scanning densitometer Model SF-TRFF with the Zeineh videophoresis program software (Biomed Instruments, Inc., Fullerton, CA) in conjunction with an Apple IIc computer. The absorption of three different bands on the film probed with CAT were compared to the absorption of a single copy $\alpha$-fetoprotein gene band (Camper and Tilghman, 1989). The ratio of the CAT absorption over the $\alpha$-fetoprotein absorption was calculated to identify homozygotes.

\section{CAT Assays}

Assays for CAT were performed essentially according to a previously described protocol (Gorman et al., 1982). Briefly, tissues were homogenized $1: 1(\mathrm{w} / \mathrm{v})$ with $0.75 \mathrm{M}$ Tris, $\mathrm{pH}$ 7.8. Insoluble debris was pelleted and the supernatant was heated to $60^{\circ} \mathrm{C}$ for $10 \mathrm{~min}$ (Crabb and Dixon, 1987). One hundred or twenty-five micrograms of protein (Bradford, 1976) was incubated in the standard assay (Gorman et al., 1982) for $4 \mathrm{hr}$ at $37^{\circ} \mathrm{C}$, and the amount of acetylated chloramphenicol was analyzed by thin-layer chromatography. Radioactive spots were cut from the plates, put in scintillation cocktail, and counted.

\section{RESULTS \\ Transgenic Lines}

We originally detected two founder animals positive for pMCA-CAT and four positive for pHCA-CAT. Of these, founder 585 for $\mathrm{pHCA}-\mathrm{CAT}$ died before offspring were born. Southern analyses of the integrants and some of their offspring are shown in Figure 1. Founder 129, and one of its offspring, and Founder 704, and two of its offspring, containing the pMCA-CAT construct, are shown after digestion of the DNA with $B a m \mathrm{HI}$, which does not cut inside the insert. Founder 129 shows a complex pattern not easily explained by a single insertion site. Founder 704 shows a simpler pattern but the number of bands are also suggestive of a complex rearrangement. As seen by the control dosage lanes, these animals have multiple copies of the insert compatible with on the order of $10-12$ in the case of 129 and a roughly similar number in 704 . Founders 133 , 586 , and 349 , with some of their offspring, containing the pHCA-CAT construct are also depicted in Figure 1 after digestion with $S a c I$ and BamHI. Again, when the DNA is digested outside the pHCA-CAT insert, multiple bands suggesting a complex or multiple intergration site pattern are seen in the case of the 133 and 586 lines, although a simpler pattern is seen in the 349 line. Approximate dosages suggest on the order of $10-$ 15 copies of the 133 line with less, perhaps five to seven in the 586 line, and a similar number of copies in the 349 line. 


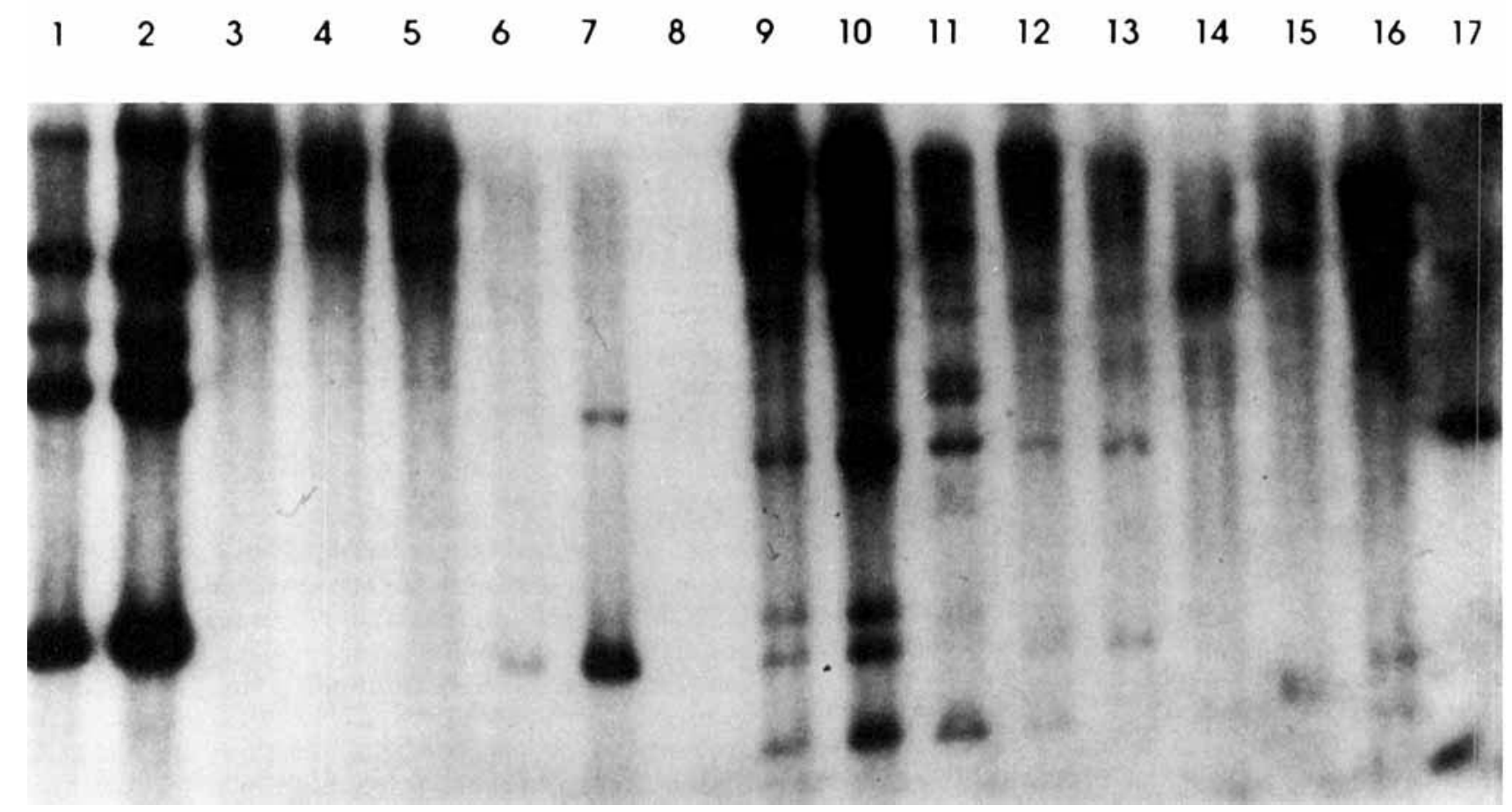

Fig. 1. Southern analysis of DNA from representative mice transgenic for pMCA-CAT and pHCA-CAT probed with bacterial CAT insert. Lanes 1-5: BamHI digestion of DNA from mice carrying pMCACAT: 1 , founder $129 ; 2$, offspring $311 ; 3$, founder $704 ; 4$, offspring 322 ; 5, offspring 328. Lanes 6-7: Control lanes containing pMCA-CAT equivalent to one copy and five copies per genome. Lanes 9-17: SacI,

\section{Expression of CAT Recorder Gene}

Multiple CAT assays were performed on founders and/or offspring to determine if appropriate tissue specific expression was achieved. As can be seen in Table 1 , background levels of expression were found in almost all cases (all the values of less than $1 \%$ conversion) except for high levels in brains of line 586 and in lung of the single deceased founder 585 . In all cases, we studied offspring that had both been transmitted through the male and through the female in case germ line imprinting (Surani et al., 1988) was responsible for the failure of expression. The high level of expression found in some mice from the 586 line, but not all, is depicted in Figure 2 along with some of the negative data for tissues such as lung and kidney, which would have also expressed if this was the regulation expected for CA II, which is also expressed at high levels in lung and kidney.

\section{Segregation of Two Inserts in Line 586}

When we studied offspring in transgenic line 586 that had integrated the pHCA-CAT construct, we were aware of the variable expression of the CAT recorder gene in brain and detected the segregation of two in-
BamHI digestion of DNA from mice carrying pHCA-CAT: 9, founder $133 ; 10$, offspring $375 ; 11$, founder $586 ; 12$, offspring $712 ; 13$, offspring $714 ; 14$, tentative founder that did not transmit $344 ; 15$, tentative founder that did not transmit $346 ; 16$, founder 349 . Lane 17: Control lane containing pHCA-CAT equivalent to one copy per genome. The filter was probed with an oligolabeled pSV2-CAT probe.

tegration patterns in the offspring. These two patterns and the typing for some animals are depicted in Figure 3 . As can be clearly seen, the complex B pattern contains almost all of the bands in the A pattern such that B is "dominant" to A. When the pedigree was followed for four generations with this in mind, it became apparent that the B pattern was associated with ectopic expression for CAT, whereas the A pattern was not (Fig. 4). This pedigree depicts only the positive animals; the segregation ratio per offspring of a parent is indicated at the right of the individuals from the mating (not all from one litter) and was not statistically different from 50\%. When a line became "pure" for the A pattern, no brain expression was found whereas consistent ectopic expression for CAT was found in animals having the $B$ integrant whether this $B$ integration was heterozygous with a nonintegrant or A integration and whether it was transmitted through a male or a female.

\section{Anatomical Localization of Ectopic Brain Expression}

As can be seen in Figure 5 and Table 2, the high expression of the recorder molecule, CAT, was primarily limited to the cerebellum. Since values above $30 \%$ 
TABLE 1. Summary of CAT Assays (\% chloramphenicol converted to acetylated form)

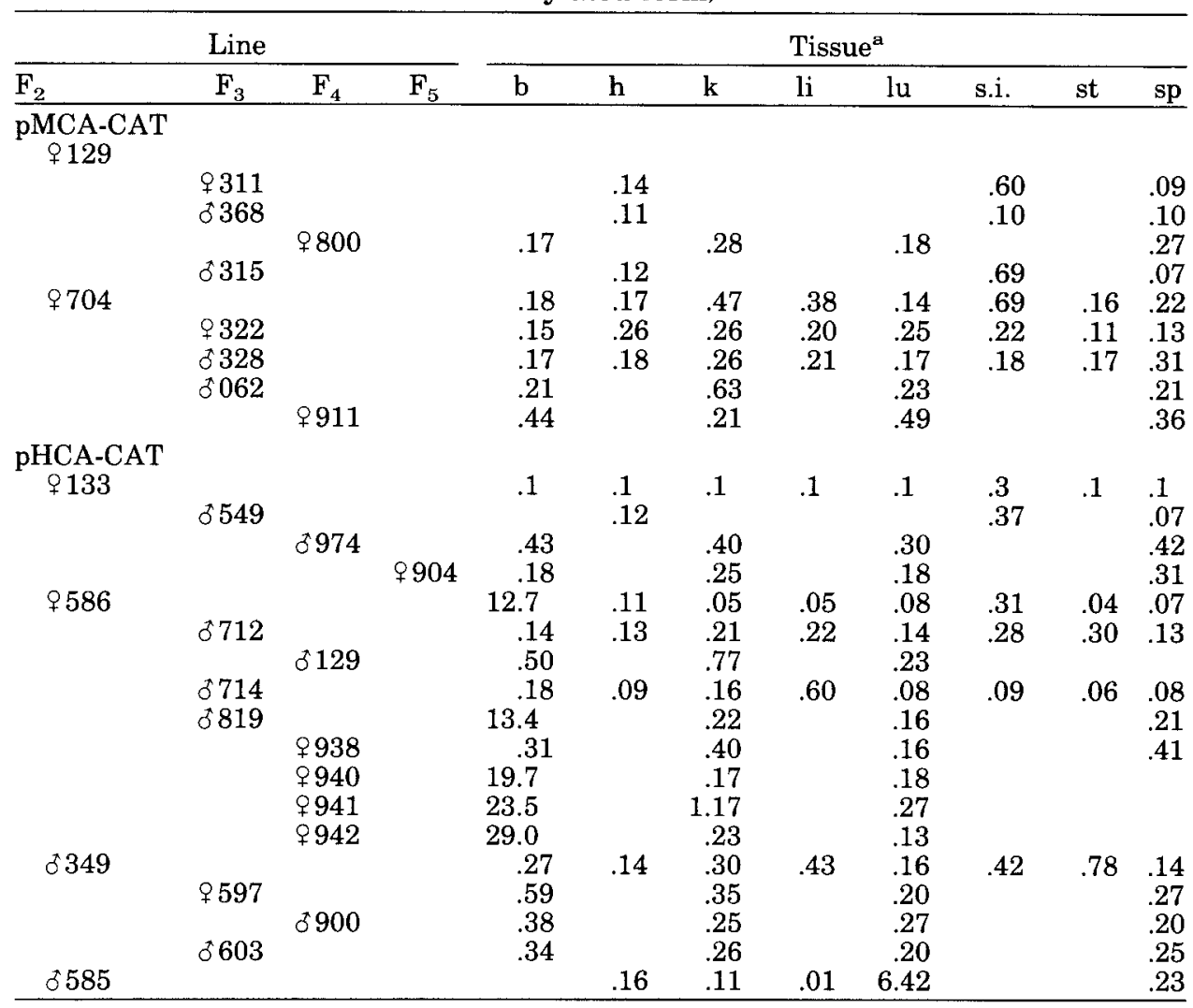

ab, Brain; h, heart; k, kidney; li, liver; lu, lung; s.i., small intestine; st, stomach; sp, spleen.

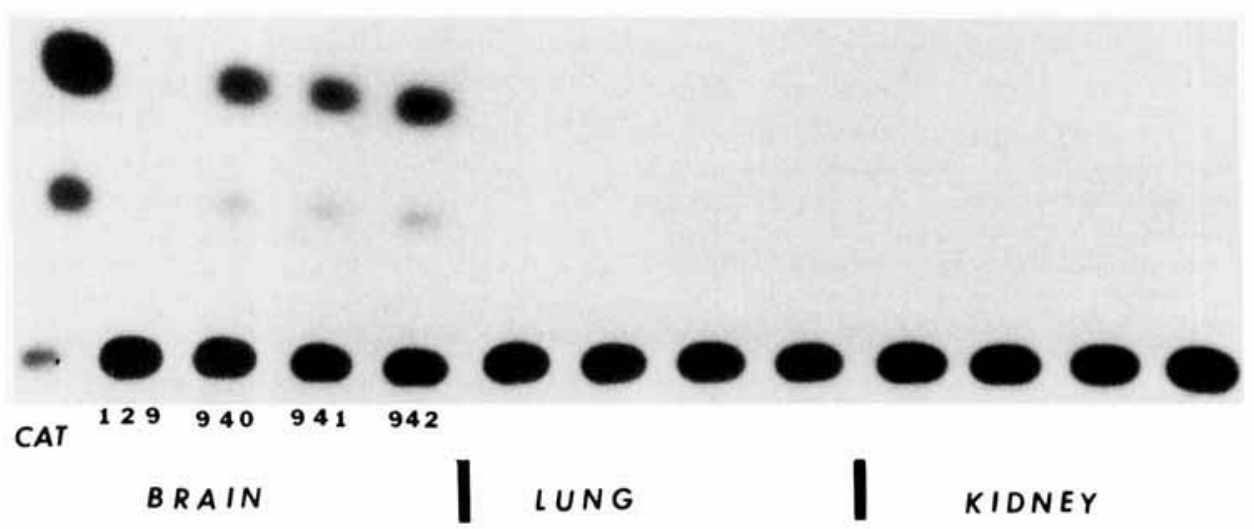

Fig. 2. Chloramphenicol acetyltransferase assays of representative tissues from four mice of the 586B line. Left margin: control of purified bacterial CAT with nearly complete acetylation of the substrate. 129: A 586A transgenic; 940,941 , and 942: 586B transgenics. The four mice are repeated in the same order with the lung and kidney samples.

conversion are not linear with respect to amount of enzyme, due to substrate depletion, the relative amount of CAT activity in cerebellum is actually much greater than depicted. Slight to moderate levels were seen in tissues such as the medulla and pons, which are most likely to be contaminated with cerebellum in these delicate dissections of fresh tissues. Thus, it seems likely that the ectopic expression was primarily in the cerebellum with a level at least tenfold higher than in any other brain tissue. 


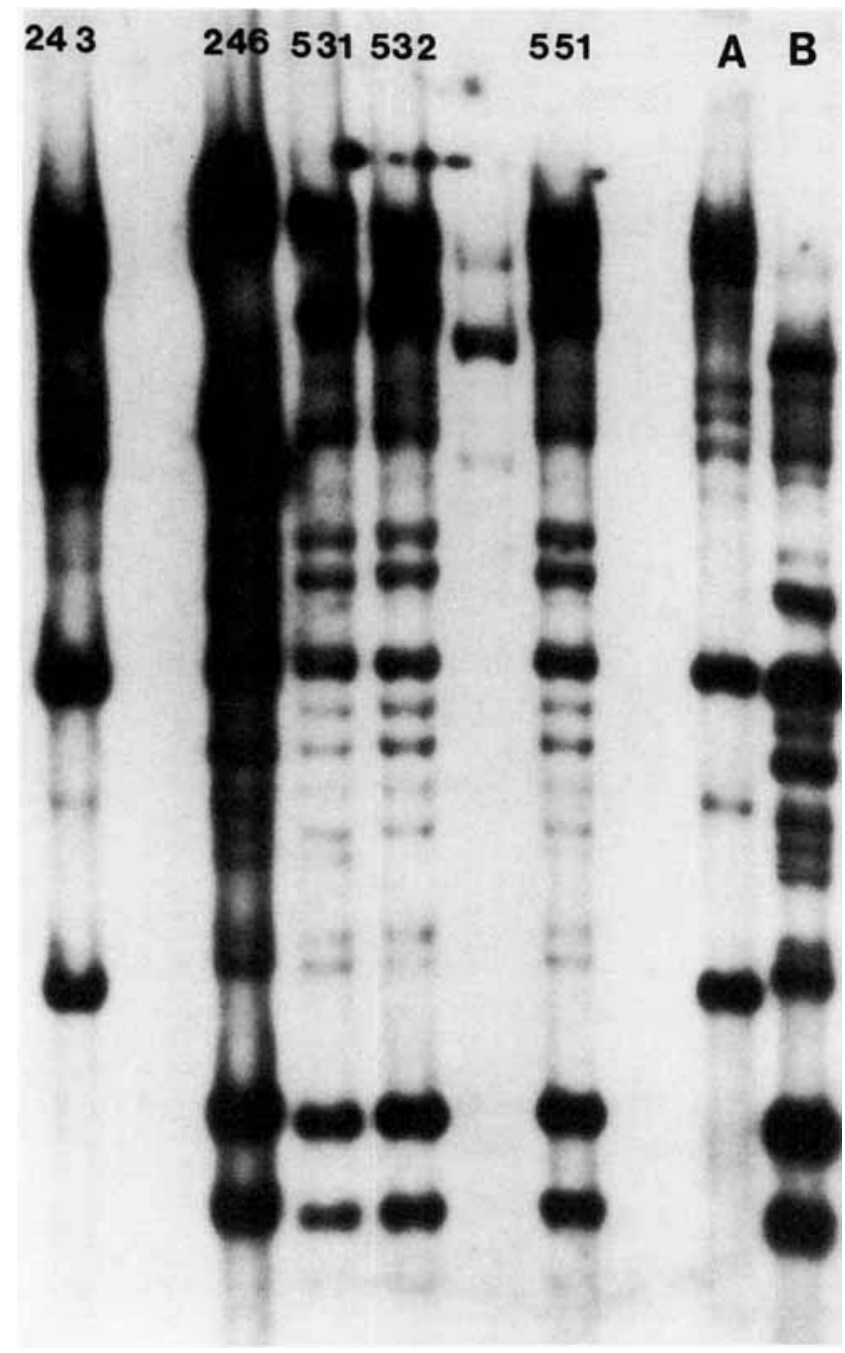

Fig. 3. Southern analysis of DNA digested with EcoRI from representative mice of the 586 line probed with bacterial CAT insert. A: A representative of the $586 \mathrm{~A}$ insertion pattern; $\mathrm{B}$ : a representative of the $586 \mathrm{~B}$ insertion pattern. 243 : a newly typed A mouse; 246,531 , 532, and 551: newly typed B mice. The few bands between 532 and 551 represent DNA from animal 547 that did not restrict well.

\section{Mice Homozygous for Integrant 586B}

We mated heterozygous mice from transgenic line $586 \mathrm{~B}$ with each other to try and determine if the integration site leading to ectopic brain expression of chloramphenicol acetyltransferase would be associated with a phenotypic effect in homozygous mice. As can be seen in Figure 5 and Table 3, apparent homozygotes were obtained as determined by dosage for several of the bands in the integrants compared to a single copy gene. Three of fourteen positive offspring appeared to be homozygotes with ratios in the range of $1.7-2.6$, with an average of $2.1 \pm 0.5$. The number of apparent homozygotes was not statistically different from the number expected $(1 / 3$, since homozygous normal are negative for the transgene and were not included). For comparison, the ratio in the parents and presumed heterozygous offspring ranged from 0.6 to 1.4 , with an average of $1.0 \pm 0.2$. Apparently homozygous mice had normal behavior in the cage and in the open field test $(0.5 \times$ $0.75 \mathrm{~m}$ ). They mated normally as evidenced by carrying litters to term. Perhaps more surprising, even with the complex motor test of swimming, they appeared normal. Thus, even homozygosity for this integrant leading to ectopic expression seems to be without phenotypic effect.

\section{DISCUSSION}

Transgenic mice formed by the insertion of DNA constructs, first successfully accomplished by Gordon et al. (1980), have become the "gold standard" for studies of regulatory regions in mammalian DNA (reviewed in Gordon and Ruddle, 1985; Palmiter and Brinster, 1986). Studies of mammalian regulatory regions using transgenic mice have shown considerable variation in the amounts and location of DNA sequences needed to achieve tissue-specific and developmental-appropriate regulation. In the case of pancreatic-specific expression of exocrine enzymes, only several hundred base pairs of 5 ' flanking sequence are needed to express elastase (Hammer et al., 1987) or amylase (Osborn et al., 1987) correctly. At the other extreme, to achieve high levels of expression of human $\beta$-globin in mice, the construct requires not only $5^{\prime}$, first intron, and $3^{\prime}$ sequences but DNAse I hypersensitive sites located approximately 15 $\mathrm{kb}$ upstream and $10 \mathrm{~kb}$ downstream from the human $\beta$-globin structural locus (Grosveld et al., 1987). It is only when these DNAse I hypersensitive sites are included in the constructs that levels of $\beta$-globin expression can be achieved in transgenic mice that are as high as those of the endogenous mouse $\beta$-globin gene. The preliminary results presented here suggest that CA II regulation may require sequence information in addition to $5^{\prime}$ flanking sequences. This is in marked contrast to the sequences needed to allow expression in cultured cells, where as little as $200 \mathrm{bp}$ sufficed (Shapiro et al., 1987).

Transgenic mice, whether produced by virus or by DNA injection, sometimes carry new mutations. Early studies on the expression of T-antigen from SV40 constructs integrated in mammalian cells showed great variability in the degree of expression between independent clones, presumably related to the different integration sites (Hanahan et al., 1980). Jaenisch's group similarly demonstrated that the mice resulting from microinjection of cloned retroviral genes showed variable patterns of expression compatible with the interpretation that the chromosomal position of the viral genome influences its activation during development (Harbers et al., 1981). A lethal mutation in the collagen I gene occurred in one of their retroviral transgenic lines of mice, and this mutation has been of great interest because of the early embryonic death that re- 


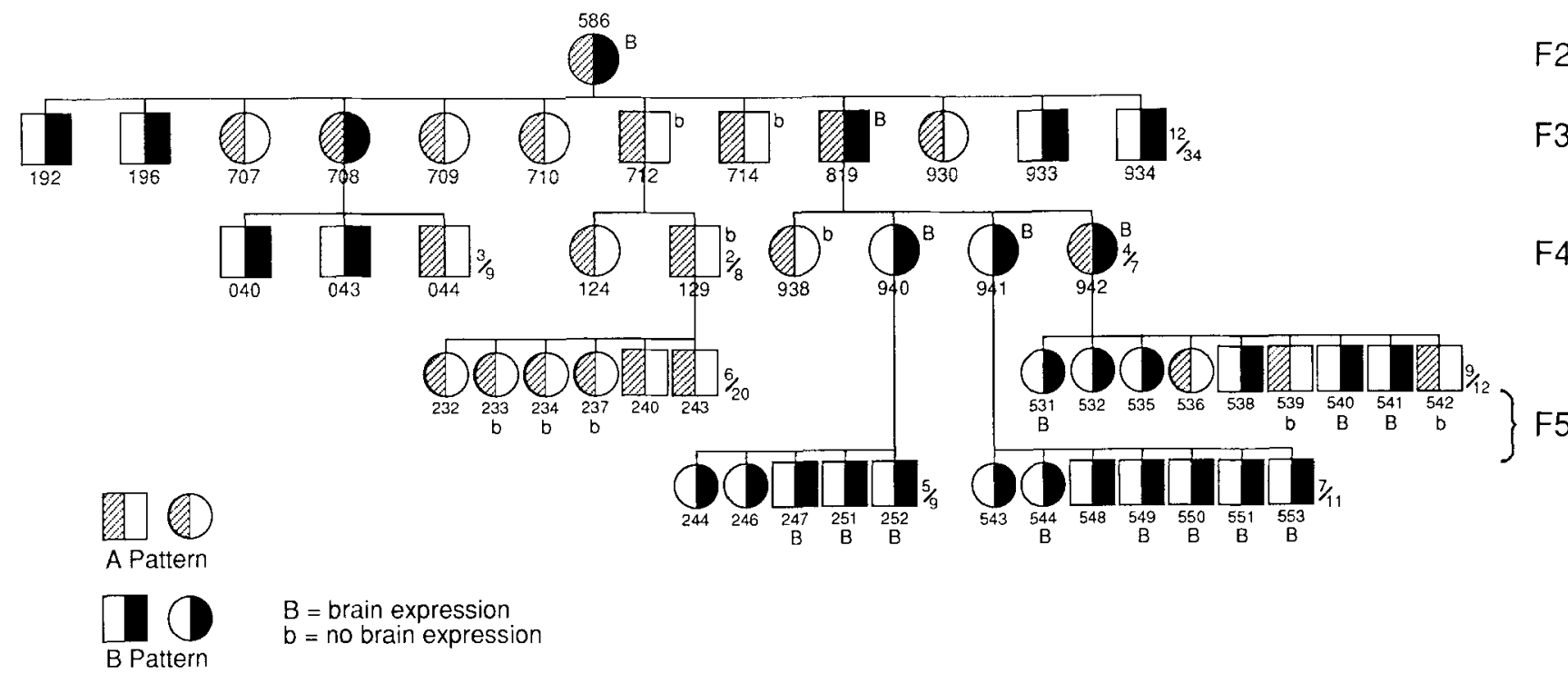

Fig. 4. Pedigree of the 586 line. Only mice positive for transgenes are depicted; the number positive/ number born is shown to the side of each subship (sometimes multiple litters). The nontransgenic mates $\left(F_{1} \mathrm{SJL} / \mathrm{J} \times \mathrm{C} 57 \mathrm{BL6} / \mathrm{J}\right)$ are not depicted.

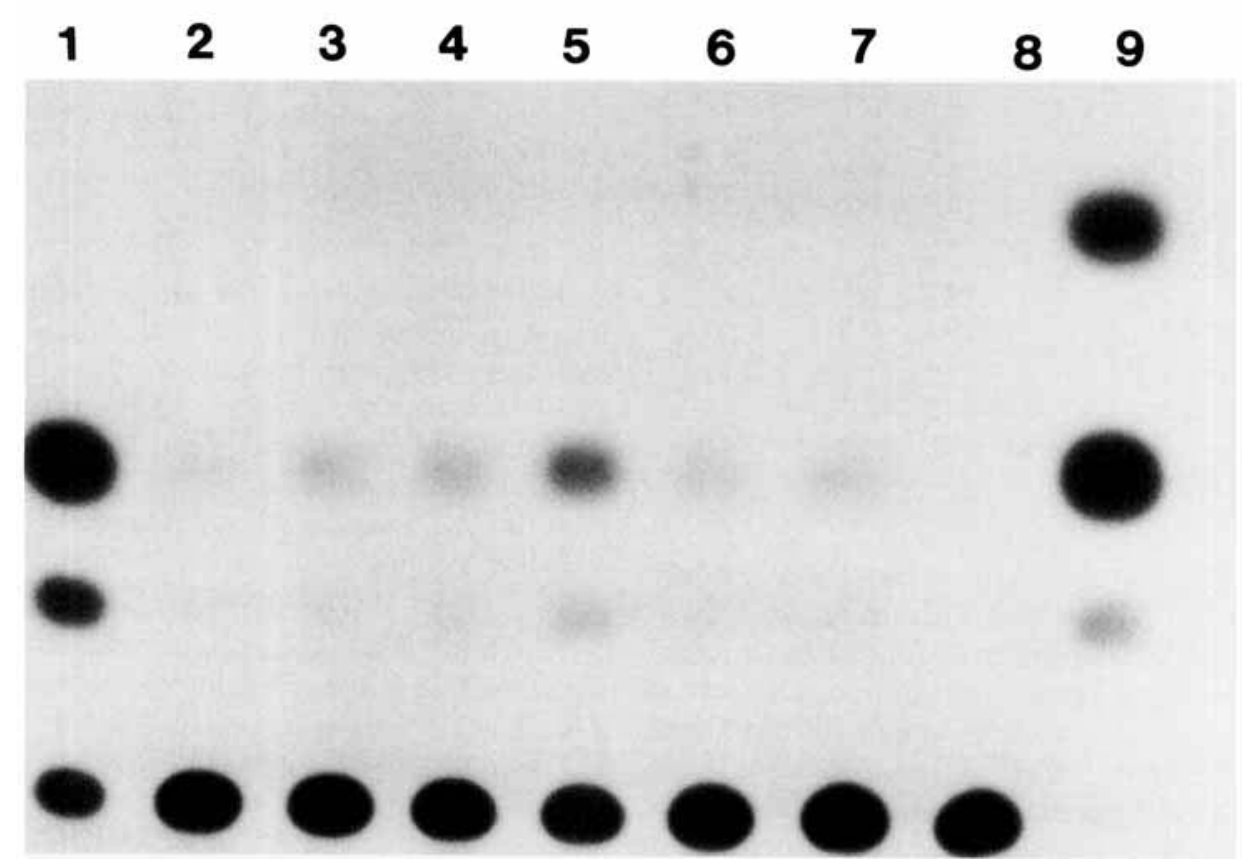

Fig. 5. Chloramphenicol acetyltransferase assays on dissected brain regions of a 586B mouse. Lane 1: Cerebellum. Lane 2: Cerebral cortex. Lane 3: Hippocampus. Lane 4: Hypothalamus. Lane 5: Medulla and pons. Lane 6: Midbrain. Lane 7: Thalamus. Lane 8: Negative control. Lane 9: Positive control of purified bacterial CAT.

sults (Jaenisch et al., 1983; Harbers et al., 1984; Breindl et al., 1984). As the creation of transgenic mice by microinjection of DNA became more common, the first insertional mutations were found (Wagner et al., 1983), and some interesting phenotypes, such as limb abnormalities, were described (Woychik et al., 1985). Although the first mutations found were recessive, dominant mutations have also been found. These have both been due to the insertional site (Wakosugi et al., 1988) or due to the activity of the inserted transgene 
TABLE 2. CAT Assays in Dissected Brains (\% chloramphenicol converted to acetylated form)

\begin{tabular}{|c|c|c|c|}
\hline \multirow[b]{2}{*}{ Tissue } & \multicolumn{2}{|c|}{ Animal } & \multirow[b]{2}{*}{ Mean } \\
\hline & $18705(q)$ & $18743(\delta)$ & \\
\hline Cerebellum & 89.9 & 76.2 & 83.0 \\
\hline Cortex & 1.44 & 1.17 & 1.30 \\
\hline Hippocampus & 2.67 & 2.94 & 2.80 \\
\hline Hypothalamus & 7.42 & 3.63 & 5.52 \\
\hline Medulla/pons & 3.01 & 15.0 & 9.00 \\
\hline Midbrain ) & & 2.65 & - \\
\hline Thalamus $\}$ & 8.81 & 3.73 & - \\
\hline Brainstem & 1.11 & - & - \\
\hline -CAT & 0.20 & 0.23 & 0.22 \\
\hline$+\mathrm{CAT}$ & 99.7 & 99.4 & 99.6 \\
\hline
\end{tabular}

TABLE 3. Densitometric Studies of Transgene Dosage in 586B Heterozygotes and Presumed Homozygotes

\begin{tabular}{cccc}
\hline Animal & $\begin{array}{c}\alpha \text {-Fetoprotein } \\
\text { absorbance }\end{array}$ & $\begin{array}{c}\text { CAT I } \\
\text { absorbance }\end{array}$ & Ratio \\
\hline Parents & & & \\
18543 & $6.0 \pm 0.4$ & $6.8 \pm 0.5$ & 1.1 \\
$\begin{array}{c}\text { 18548 } \\
\text { Offspring }\end{array}$ & $5.5 \pm 0.8$ & $5.4 \pm 0.5$ & 1.0 \\
711 & $3.1 \pm 0.6$ & $3.0 \pm 0.3$ & 1.0 \\
712 & $3.0 \pm 0.5$ & $7.8 \pm 0.2$ & $2.6^{\mathrm{b}}$ \\
714 & $5.5 \pm 9.5$ & $4.5 \pm 0.2$ & 0.8 \\
715 & $3.7 \pm 0.4$ & $4.8 \pm 0.3$ & 1.3 \\
716 & $9.0 \pm 0.7$ & $7.0 \pm 0.1$ & 0.8 \\
718 & $9.3 \pm 0.5$ & $9.8 \pm 0.8$ & 1.1 \\
719 & $8.0 \pm 0.7$ & $5.5 \pm 0.4$ & 0.7 \\
731 & $6.8 \pm 0.5$ & $9.6 \pm 0.7$ & 1.4 \\
734 & $2.4 \pm 1.1$ & $4.0 \pm 0.9$ & $1.7^{\mathrm{b}}$ \\
735 & $6.7 \pm 0.5$ & $8.5 \pm 0.9$ & 1.3 \\
736 & $5.6 \pm 0.4$ & $6.5 \pm 0.8$ & 1.2 \\
737 & $5.1 \pm 0.5$ & $9.7 \pm 0.8$ & $1.9^{\mathrm{b}}$ \\
738 & $4.0 \pm 0.4$ & $4.0 \pm 0.2$ & 1.0 \\
740 & $4.7 \pm 0.4$ & $2.8 \pm 0.2$ & 0.6 \\
\hline
\end{tabular}

arbitrary absorbance units, mean $\pm \mathrm{SD}$.

${ }^{b}$ Presumed homozygotes.

itself (Gordon, 1986). Male sterility has been a fairly common phenotype (Wilkie and Palmiter, 1987; Iwakwia et al., 1988). Our results are somewhat unusual in that we have integrated a transgene in a site that leads to activation of the recorder molecule but there seems to be no phenotypic effect of this insertion. If the insertion was into an expressed gene, it would be surprising if some effect on the gene's expression was not found. However, it is possible that the insertion event is upstream of an enhancer. Since enhancers have a nondirectional influence on gene expression, the insertion could result in no alteration of expression to a normal gene downstream of a putative enhancer. Additionally, however, it was surprising that the ectopic expression of CAT, a bacterial protein, had no effect on the animals. Presumably other cases will be found in which active gene integrants are without phenotype. Perhaps this is a measure of the redundancy of the genome.

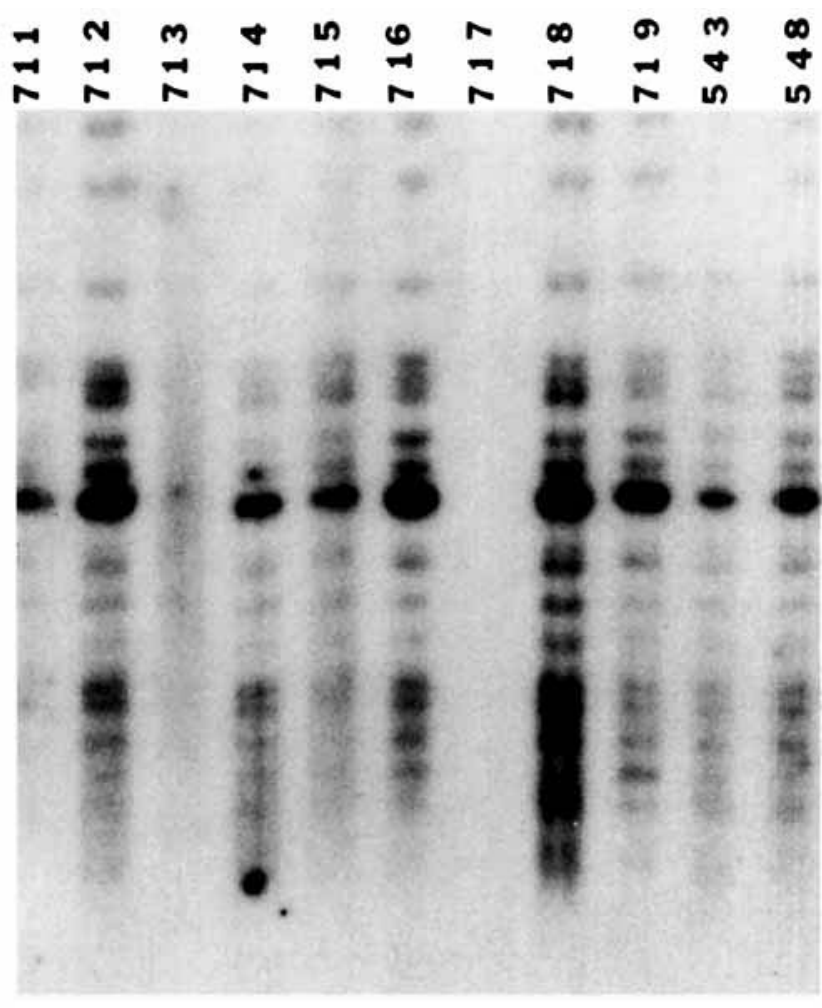

Fig. 6. Southern analyses of DNA digested with $E c o$ RI from offspring of a $586 \mathrm{~B} \times 586 \mathrm{~B}$ cross probed with bacterial CAT insert. 712 is a putative homozygote as indicated by dosimetry.

It is interesting that the major CA isozyme normally found in mouse brain is CA II. However, it is specifically expressed in oligodendrocytes (Ghandour et al., 1989), which are abundant in the cerebral cortex, cerebellum, and corpus callosum. Thus, the distribution of normal CA II is quite different from the ectopic expression of CAT found with our insert.

\section{ACKNOWLEDGMENTS}

We thank Ms. Leann Kinnunen for technical assistance and Ms. Judy Worley for secretarial assistance. This work was supported by NIH grants HD20670 to R.P.E. and GM24681 to R.E.T.

\section{REFERENCES}

Beechey C, Tweedie S, Spurr N, Peters J, Edwards Y (1989): Mapping of mouse carbonic anhydrase-3, Car-3: A further locus in the homologous region of mouse chromosome 3 and human chromosome 8 . Genomics (in press).

Bradford MM (1976): A rapid and sensitive method for the quantitation of microgram quantities of protein utilizing the principle of protein-dye binding. Anal Biochem 72:248-254.

Breindl M, Harbers K, Jaenisch R (1984): Retrovirus-induced lethal mutation in collagen I gene of mice is associated with an altered chromatin structure. Cell 38:9-16.

Camper SA, Tilghman SM (1989): Postnatal repression of the $\alpha$-fetoprotein gene is enhancer independent. Genes Dev 3:537-548.

Crabb DW, Dixon JE (1987): A method for increasing the sensitivity 


\section{ECTOPIC EXPRESSION IN TRANSGENIC MICE}

of chloramphenicol acetyltransferase assays in extracts of transfected tissue culture cells. Anal Biochem 163:88-92.

Edwards YH, Barlow JH, Konialis CP, Povey S, Butterworth PHW (1986): Assignment of the gene determining human carbonic anhydrase, CA I, to chromosome 8. Ann Hum Genet 50:123-129.

Eicher EM, Stern RH, Womack JE, Darisson MT, Roderick TH, Reynolds SC (1976): Evolution of mammalian carbonic anhydrase loci by tandem duplication: Close linkage of Car-1 and Car-2 to the centromere region of chromosome 3 of the mouse. Biochem Genet 14:651-660.

Ghandour MS, Skoff RP, Venta PJ, Tashian RE (1989): Oligodendrocytes express a normal phenotype in carbonic anhydrase II-deficient mice. J Neurosci Res 231:180-190.

Gordon JW (1986): A foreign dihydrofolate reductase gene in transgenic mice acts as a dominant mutation. Mol Cell Biol 6:2158-2167.

Gordon JW, Ruddle RH (1986): DNA-mediated genetic transformation of mouse embryos and bone marrow-A review. Gene 33:121136

Gordon JW, Scangos JA, Plotkin DJ, Barbosa JA, Ruddle FH (1980): Genetic transformation of mouse embryos by microinjection of purified DNA. Proc Natl Acad Sci USA 77:7380-7384.

Gorman CM, Moffat LF, Howard BH (1982): Recombinant genomes which express chloramphenicol acetyltransferase in mammalian cells. Mol Cell Biol 2:1044-1051.

Grosveld F, van Assendelft GB, Greaves DR, Kollias G (1987): Position-independent, high-level expression of the human $\beta$-globin gene in transgenic mice. Cell 51:975-985.

Hammer RE, Swift GH, Ornitz DM, Quaife CJ, Palmiter RD, Brinster RL, MacDonald RJ (1987): The rat elastase I regulatory element is an enhancer that directs correct cell specificity and developmental onset of expression in transgenic mice. Mol Cell Biol 7:2956-2966.

Hanahan D, Lane D, Lipsich L, Wigler M, Botchan M (1980): Characteristics of an SV40-plasmid recombinant and its movement into and out of the genome of a murine cell. Cell 21:127-139.

Harbers K, Jähner D, Jaenisch R (1981): Microinjection of cloned retroviral genomes into mouse zygotes: Integration and expression in the animal. Nature 293:540-542.

Harbers K, Kuehn M, Delius H, Jaenisch R (1984): Insertion of retrovirus into the first intron of aI(I) collagen gene leads to embryonic lethal mutation in mice. Proc Natl Acad Sci USA 81:1504-1508.

Hogan B, Costantini F, Lacy E (1986): "Manipulating the Mouse Embryo: A Laboratory Manual." Cold Spring Harbor, NY: Cold Spring Harbor Laboratory Press, pp 89-204.

Iwakwia Y, Asano M, Nishimune Y, Kawade Y (1988): Male sterility of transgenic mice carrying exogenous mouse interferon- $\beta$ gene under the control of the metallothionein enhancer-promoter. EMBO J 7:3757-3762.

Jaenisch R, Harbers K, Schnieke A, Löhler J, Chumakor J, Jähner D, Grotkopp D, Hoffman E (1983): Germline integration of moloney murine leukemia virus at Mov13 locus leads to recessive lethal mutation and early embryonic death. Cell 32:209-216.

Kendall A, Tashian RE (1977): Erythrocyte carbonic anhydrase I (CAI): inherited deficiency in humans. Science 197:471-472.

Lewis SE, Erickson RP, Barnett LB, Venta PJ, Tashian RE (1988): N-Ethyl-N-nitrosourea-induced null mutation at the mouse Car-2 locus: An animal model for human carbonic anhydrase II deficiency syndrome. Proc Natl Acad Sci USA 85:1962-1966.

Nakai H, Byers MG, Venta PJ, Tashian RE, Shows TB (1987): The gene for human carbonic anhydrase II (CA2) is located at chromosome 8q22. Cytogenet Cell Genet 44:234-235.

Osborn L, Rosenberg MP, Keller SA, Meisler MH (1987): Tissue-specific and insulin-dependent expression of a pancreatic amylase gene in transgenic mice. Mol Cell Biol 7:326-334.

Palmiter RD, Brinster RL (1986): Germ-line transformation of mice. Annu Rev Genet 20:465-499.

Shapiro LH, Venta PJ, Tashian RE (1987): Molecular analysis of $\mathrm{G}+\mathrm{C}$-rich upstream sequences regulating transcription of the human carbonic anhydrase II gene. Mol Cell Biol 7:4589-4593.

Sly WS, Hewett-Emmett D, Whyte MP, Yu Y-SL, Tashian, RE (1983): Carbonic anhydrase II deficiency identified as the primary defect in the autosomal recessive syndrome of osteopetrosis with renal tubular acidosis and cerebral calcification. Proc Natl Acad Sci USA 80: $2752-2756$

Surani MA, Reik W, Allen ND (1988): Transgenes as molecular probes for genomic imprinting. Trends Genet 4:59-62.

Tashian RE (1989): The carbonic anhydrases: Widening perspectives on their evolution, expression, and function. BioEssays 10:186-192.

Tashian RE, Hewett-Emmett D, Dodgon SJ, Forster RE, Sly WS (1984): The value of inherited deficiencies of human carbonic anhydrase isozymes in understanding their cellular roles. Ann NY Acad Sci 429:262-275.

Venta PJ, Montgomery JC, Hewett-Emmett D, Tashian RE (1985): Comparison of the $5^{\prime}$ regions of human and mouse carbonic anhydrase II genes and the identification of possible regulatory elements. Biochim Biophys Acta 86:195-201.

Wagner EF, Covarrobias L, Stewart TA, Mintz B (1983): Prenatal lethalities in mice homozygous for human growth hormone gene sequences integrated in the germ line. Cell 35:647-655.

Wakosugi S, Kwanaga T, Inomooto T, Tengan T, Maeda S, Uehira M, Araki K, Miyayaki J, Eto K, Shimada K, Yamamevia K (1988): An autosomal dominant mutation of facial development in a transgenic mouse. Dev Genet 9:203-212.

Wilkie TM, Palmiter RD (1987): Analysis of the integrant in MyK103 transgenic mice in which males fail to transmit the integrant. Mol Cell Biol 7:1646-1655.

Woychik RP, Stewart TA, Davis LG, D'Eustachio P, Leder P (1985): An inherited limb deformity created by insertional mutagenesis in a transgenic mouse. Nature 318:36-40. 